\title{
The development of positive mounting on efficiency increase of mastery in marketing among engineering university students
}

\author{
Nikolay Sajgushev ${ }^{1 \mathrm{a}}$, Lubov Savva ${ }^{1}$, Olga Vedeneeva $^{1}$, and Alexander Tsaran ${ }^{1}$ \\ ${ }^{1}$ Magnitogorsk state technical university, 455000 Lenina str., 38, Magnitogorsk, Russia
}

\begin{abstract}
This article deals with the conditions of positive mounting on efficiency increase of mastery in marketing among engineering university students: creating a way for future professional activities; creating a reflexive orientation process of mastery in marketing; the formation of a positive emotional background value of students' interaction in the process of joint training and learning activities; the emotions as one of the main mechanisms of internal regulation of mental human activities and behavior and a number of factors which must be taken into account when establishing the conditions for emotional value communication in the process of group interaction.Considering the pedagogical conditions concerning the formation of positive mounting on efficiency increase of mastery in marketing among engineering university students, we can conclude that each of the selected conditions promotes the mastery in marketing, but only their integral complex makes this process effective.
\end{abstract}

\section{Introduction}

Marketing today is a fundamental element of the processing system concerning competitive advantages and abilities of organizations. The importance of marketing in the management of modern economic processes and market needs for such specialists dictate certain requirements to the level of vocational training experts in marketing, showing the the formation of their positive attitudes to increase the effectiveness of mastering the profession.

Formation method of future professional activities is central to motivating active cognitive activity of students. And as indicated in the scientific literature until the clear meaning of discipline from the perspective of the needs of future careers, that the range of tasks that her study will help solve, cannot expect the students' activities [1].

\section{Materials and methods}

The goals and objectives of our research identified the following set of methods - theoretical analysis of literature on the research problem; the analysis of regulatory documents; the comparative analysis of educational systems; modeling; questioning and testing; the method of expert evaluations; a pedagogical experiment, observation, studying the products of pedagogical activities; a functional and feature-based analysis and other research methods.

\section{The complex of organizational- pedagogical conditions providing the effectiveness of the research}

\section{The formation method of the future professional activities}

Implementation of marketing requires not only basic initial training, but also needs much knowledge in the field of organization and economic of production, trade, civil and administrative law, finance, sociology, psychology, economics and mathematical methods, advertising and other disciplines and special studies [7]. Summarizing the requirements of marketers' personal qualities, the following can be: an adequate level of special education; a pronounced tendency to innovation; lack of attachment to the rigid schemes and structures; propensity to constant self-improvement; normal perception of opposing opinions and the ability to argue in a correct way; a high sense of moral responsibility; an analytical mind; developed intuition; the ability to accumulate information coming from such sources as suppliers, competitors, customers, personnel company, the surrounding social and political environment; the ability to believe; subtle psychology, the external representation; a good sense of humor, coupled with the tenacity and aggressiveness at work; willingness to take risks and to be in one 's own mind.

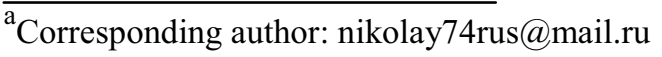


A marketer should know the methods of marketing research, analysis of the marketing environment and economic analysis of the enterprise activity, identify and predict the assortment policy, the choice of distribution channels, organization and carrying out promotional activities and sales promotion of goods [10]. He must surely possess both these methods, and skills to develop a strategy and tactics of the enterprise as a whole.

In his article "Marketing Changes to Survive?" Professor of marketing Kamran Kashan brings the results of the international survey of more than 200 general managers and managers of marketing services [6]. More than $90 \%$ of all respondents from different countries and business sectors had the opinion that marketing in their organizations has undergone major changes and come out of them stronger both in terms of its status and influence on strategic decision-making.

In this regard, the respondents ranged the problems in the field of marketing and management in accordance with their importance to the business:

- improvement of product and/or service;

- development of new products;

- maintaining contacts with consumers;

- extension or improvement of customer service;

- monitoring competitors ' activities;

- relationship marketing with other functions;

- create a marketing culture in the organization;

- price competition;

- focus on new segments;

- increase the productivity of marketing cost;

- differentiation of the brand or image corporation;

- improving distribution channels;

- effective advertising and promotion;

- environmental problems;

- European integration;

- marketing in terms of government regulation.

Total of individual skill and individual competence marketers distributed the following severity levels:

- strategic thinking;

- ability to communicate;

- ability to feel the needs of the customers;

- ability to manage people;

- entrepreneurial streak;

- focus on service;

- innovation;

- negotiating skills;

- ability to solve analytical problems;

- international orientation and knowledge;

-knowledge of other functions in addition to marketing;

- general management skills;

- skills in computer data processing;

- special marketing skills.

The first three individual competences are far superior in their importance to the future success of the activities of all other marketers. It is particularly important to note that all critical abilities having the first positions in the list are of a general nature. Indeed, the ' special ' marketing skills were identified by the respondents at the end of the list, i.e. were evaluated as less relevant for successful marketing activities. Thus, respondents indicated that the increasing complexity of future marketing requires a greater palette of basic abilities, which clearly goes beyond the specialized knowledge and skills. They also pointed to the existence of a more specific level of compensation managers with the ability to see prospects for the development of their markets, as well as to subtly perceive information that comes from customers and other individuals inside and outside of their organization, which is the essence of effective communication.

B. Sekerin, E. Molchanovsky and Y. Tolokonnikova argue that a marketer is both a marketing researcher and a psychologist and a sociologist, and economist and specialist in the field of communications, and a lawyer [11].

In addition, marketers must possess basic knowledge in mathematics and statistics or at least have the abilities to their acquisition. Working with numbers and methods of marketing research, they should feel comfortable. Their professional growth and career advancement depends on the ability to effectively apply existing knowledge and skills, and acquire new ones. Successful marketers work "ahead of the curve" events rather than react to their effects, i.e. they try to identify and lead a promising direction and research, rather than simply to provide information issued the order. A good researcher understands that market research is carried out with the only purpose - to help you make more educated marketing solution. Thus, it is better suited to the role of employee giving advice to others than taking responsibility for the decision. Professional growth and advancement of the representatives of the profession depends on the ability to effectively apply existing knowledge and skills, and acquire new ones.

Table 1. Qualification matrix of a marketer.

\begin{tabular}{|c|c|c|c|}
\hline Skills and abilities & $\begin{array}{c}\text { Low } \\
\text { level } \\
\text { (less than } \\
3 \text { years of } \\
\text { work) }\end{array}$ & $\begin{array}{l}\text { Middle } \\
\text { level (3- } \\
7 \text { years } \\
\text { of work) }\end{array}$ & $\begin{array}{c}\text { High } \\
\text { level } \\
\text { (more } \\
\text { than } 7 \\
\text { years of } \\
\text { work) }\end{array}$ \\
\hline \multicolumn{4}{|c|}{ Technical skills and abilities } \\
\hline $\begin{array}{l}\text { Computer literacy } \\
\text { Ability to work with } \\
\text { statistical } \\
\text { data/Design sample } \\
\text { Statistical analysis } \\
\text { Database } \\
\text { management } \\
\text { Creating a model } \\
\text { Managing a project } \\
\text { Knowledge in the } \\
\text { field of research } \\
\text { System design } \\
\text { (Marketing } \\
\text { processes) } \\
\text { Development of } \\
\text { project concept }\end{array}$ & $\begin{array}{l}* \\
*\end{array}$ & $\begin{array}{l}* \\
* \\
* \\
* \\
* \\
*\end{array}$ & $\begin{array}{l}* \\
* \\
* \\
* \\
* \\
*\end{array}$ \\
\hline \multicolumn{4}{|c|}{ Managing skills and abilities } \\
\hline $\begin{array}{l}\text { Communications } \\
\text { Statistical analysis } \\
\text { Making reports } \\
\text { Coordinating }\end{array}$ & $\begin{array}{l}* \\
* \\
* \\
*\end{array}$ & $\begin{array}{l}* \\
* \\
* \\
*\end{array}$ & $\begin{array}{l}* \\
* \\
* \\
*\end{array}$ \\
\hline
\end{tabular}




\begin{tabular}{|l|l|l|l|}
\hline projects & $*$ & $*$ \\
Coordinating people & & $*$ & \\
MotivationTask & & $*$ & $*$ \\
definition & & $*$ & $*$ \\
Personnel training & & & $*$ \\
Finning/Strategy & & & $*$ \\
administration & & & \\
\hline
\end{tabular}

In the qualification matrix of a marketer (Table 1) compiled by the American Marketing Association provides a set of technical skills and abilities needed to work in the field of marketing research [4].

Researchers N.Y Sajgushev, Z.A. Resetova, E. Loginova, S. Baljaeva, O.A Vedeneeva, etc. concluded that the systematic method of analysis of educational activity gives an opportunity to its reflection by students, and on this basis - the possibility of self-organization of mental activity [3,9]. As a result, the student can select activities, assess the nature of the necessary funds, to correlate an objective with the terms of its achievements, assess the final product as reached or not reached goal, outline implementation plan as a whole.

All this analysis gives the ability to build generalized indicative framework action to address professional challenges.

The formation method of future professional activities must be based on the algorithm of professional activities in marketing, which is strictly deterministic sequence of stages of this activity. One of the important results of the implementation of the generalized algorithm professional activities is forming a marketing knowledge base, containing, as a required element, a system for monitoring the effectiveness of marketing activities, it allows to begin a new cycle of realizing generalized algorithm.

\section{Creating a reflexive orientation to the process of mastering the profession of a marketer}

Learning basic strategy of a future marketer aims to interact, which encourages creative exploration of professional experience, self-knowledge, selfdevelopment. This strategy aims at the cultivation of reflexive "I" and the ability to work in a team, as well as to personify oneself in various occupations.

Reflexive environment opens a possible field for free (conscious) choice prospects for values, forms and means of self-fulfillment and self-development, gives the opportunity to develop a unique individual way of creative life of the future of marketer, to test it, to identify constructive potential and to move from special conditions (e.g., reflepraktikuma) into other areas and aspects of life.

In addition, it is important to create an environment in which each participant receives positive interpersonal experience of living individual and group interaction in simulated situations of professional activity.

Reflexive orientation is linked to the readiness of the future in marketing to re-comprehension and overcoming life and professional issues; effective output from internal and external conflict and situations; acquisition of new forces, meanings and values; staging and imaginative solution of practical tasks.

Adequately established reflexive orientation provides opportunities for students' self-discovery and, therefore, to transform stereotypes of his personal and professional experience; for the implementation of the plastic and constructive integration generated as a result of this innovation in the system of vocational activities, business and interpersonal relationships $[2,3,9]$.

The subject to the provisions of the reflexive focus let us formulate the following requirements for reflective organization of educational-cognitive engineering university students' activities:

1) ensuring the process of mastering the profession through the organization of its activities (educational, professional);

2) the formation of ideas about educational-cognitive activities as personally and professionally meaningful;

3 ) the formation and development of students' ideas about the educational activities as the factor of formation of professional and general personality.

Creating a reflexive direction for future marketers, while mastering the profession contributes the following: intensifying reflexive-innovative capacity developing personality; rethinking its professional experience; readiness for professional creativity; expansion of current and potential fields of reflection in professional activities.

In connection with the above, appears one of the particular tasks of our further practical work-selection of adequate methods of teaching students while we relied mainly on active, discussion and reflexive learning techniques. From our point of view, they have the best absorption of theoretical and practical study material for marketing.

The main methods of positive mounting on efficiency increase of mastery in marketing among engineering university students are problem lectures, pre-planned errors, workshops, labs, independent work on the individual topic trainings, workshops, independent work on scientific research, a roundtable conference, reflexive group workshops, conducting business games ("Entrepreneur and Company", "Marketing and Entrepreneur", "Company Strategy", "Effectiveness", "Production Management") and other forms of learning. These methods are implemented in the classroom education and special educational disciplines during extracurricular activities of students in a specially organized reflexive environment.

An important role in the educational future careers way in marketing is a meaningful component of academic disciplines studying the Russian labor market requirements with regard to the preparation of the marketers.To promote and develop intellectual and regulatory reflection of a future marketer the knowledge about different approaches to professional activities, about how to organize them are necessary, creating a complete picture of their professional activities, and comparing those requirements to the professional 
situation, and existing regulations governing the following activities.

\section{The formation of the positive backdrop of emotionally valuable interaction among students in the process of collaborative learning- cognitive activities}

Turning to the third condition which we define as follows: the formation of a positive emotional background value of the students' interaction in the process of joint training and learning activities.

Emotions were one of the main mechanisms of internal regulation of mental human activities and behavior. Human emotions are complex and multifaceted, as they reflected not only a feeling in the physiological sense but also a person's public relations, the worldview, the attitude to the acts and statements of other people because emotional saturation of an organism is its important innate and growing demand, and during their training and learning activities future marketers should rely on their emotional sphere.

In the process of interaction among the students there are various emotions. Some enrich activities reinforce interest in it, others cause indifference. Their difficulties, constant failures and blunders, hurtful comments not only disappoint students but also can lead to total loss of interest in learning. The emotional support of a student by a teacher and training unit is a powerful incentive to achieve results. The relationships based on trust, mutual respect and assistance determine the psychological wellbeing and the health of the student form a sense of social and emotional security, promote communication and positive aspects "I" student.

Interoperability future marketers happening in an atmosphere of a certain psychological climate which affects the level of mental activity for each student. Division of strengths and weaknesses, underscore the success of some and the focus on the failures of others, improper allocation of roles, insufficient analysis of individual success and the joint activities of the study group would inevitably lead to disruption in interpersonal relationships, to forgo the interaction. It follows that the psychological climate and mood study group should be the subject of special attention from the teacher.

It means that in a favourable psychological climate there is a real opportunity to personal self-fulfillment and productive joint training and learning activities of students. In other words, emotionally-value interaction provides a favourable emotional climate training.

Emotionally-value interaction future marketers during joint training and learning activities we associate with motivation. High positive motivation may play a compensatory role in case of insufficient high abilities or insufficient stock of the required knowledge and skills.

An important aspect of motivation group interaction is a common goal, which is recognized as a training unit and serves as an incentive for the joint efforts of students in achieving the result to address the educational challenges. The success of achieving the common goal influences a number of factors which must be taken into account when establishing the conditions for emotional value communication future marketers in the process of group interaction. We distinguish such factors as the type of contacts inside the training unit (cooperation, rivalries, individual responsibility), interaction mode ("chain"; "circle"; "the wheel"; "multi-channel"), the quantitative and qualitative composition of team training, leadership in the training unit.

The modes of group interaction are presented in Fig. 1.

a)
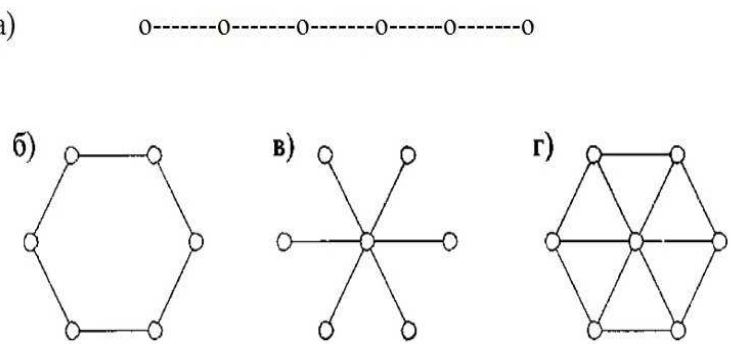

Fig. 1. The modes of group interaction: a) "chain"; b) "circle"; c) "wheel"; d) "multichannel"

The mode "chain": the process of a task is divided into a number of sequentially executed operations, each of which is assigned to a single student. The mode "circle": the process can be arranged cyclically so that the end of the cycle is the beginning of the second. In the "wheel" all communications in the group are made through one person, usually the leader of the group, so the effectiveness of the group will be determined by the abilities of the person in the centre. Decisions or conclusions are reached most quickly, but the most difficult tasks cannot be done. During the multichannel mode of interaction each group member can communicate directly with any other member of the group. When considering complex problems the multichannel mode is most suitable to develop the best solutions.

It is obvious that the group interaction among future marketers cannot be considered optimal if training is not actively involved tasks, but only prepared by its members. The other trainees are restricted to the support functions; they tend to remain in the shadows, condemned to inactivity. However, each student has their own view on the issue and how to resolve it. If group members feel that their work is perceived as meaningful and making an important contribution to the attainment of the objectives of the organization they are more likely to be motivated to carry out their work.

Thus, each of the selected conditions contributes to mastering the profession marketer engineering university students, but only their holistic complex makes this process effective.

\section{Conclusion}


Thus, considering the pedagogical conditions concerning the formation of positive mounting on efficiency increase of mastery in marketing among engineering university students, we can conclude that each of the selected conditions promotes the mastery in marketing, but only their integral complex makes this process effective.

This article deals with the conditions of positive mounting on efficiency increase of mastery in marketing among engineering university students: creating a way for future professional activities; creating a reflexive orientation process of mastery in marketing; the formation of a positive emotional background value of students' interaction in the process of joint training and learning activities; the emotions as one of the main mechanisms of internal regulation of mental human activities and behavior and a number of factors which must be taken into account when establishing the conditions for emotional value communication in the process of group interaction.

\section{References}

1. A.A. Dergacha, Acmeology (M.: Izd-vo RAGS, 2002)

2. I. B. Ardashkin, N. V. Martyushev, V. P. Bezborodov, SBS Journal, 166, (2015)

3. M.G. Majid, P. Selvan, M.N.Nor Azila, ASS, 10 (2014)

4. G.A. Cherchill, Marketingovyie issledovaniya (SPb.: Piter, 2000)

5. Z. Reshetova, E. Loginova, S. Balyaeva, Formirovanie sistemnogo myishleniya $v$ obuchenii (M., 2002)

6. K. Kashani, Marketing, 1, (1998)

7. L. Kochurova, Torgovlya, 9, 12 (1993)

8. I. Mann, $100 \%$ Marketing (M .: MIF, 2011)

9. A.V. Karpov, I.N. Semenov, Refleksivnyiy podhod v psihologicheskom obespechenii obrazovaniya (M., 2004)

10. D. Amer, S.R. Subramaniam, M.N. Nor, Z.A. Zarina, Internat. Jour. of Econom. Research, 11, 1, (2014)

11. V. Sekerin, E. Molchanovskiy, Yu. Tolokonnikova Marketing, 6(b1), (2001)

12. I.A. Rudaleva, I.A. Kabasheva, SBS Journal, 152, (2014)

13. T. Vakhitova, L. Gadelshina, SBS Journal, 152, (2014) 